\title{
Nitrifier characteristics in submerged membrane bioreactors under different sludge retention times
}

\author{
Tao Yu, Rong Qi, Dong Li, Yu Zhang, Min Yang* \\ State Key Laboratory of Environmental Aquatic Chemistry, Research Center for Eco-Environmental Sciences, Chinese Academy \\ of Sciences, 18 Shuangqing Road, Haidian District, Beijing 100085, China
}

\section{A R T I C L E I N F O}

Article history:

Received 28 October 2009

Received in revised form

3 February 2010

Accepted 16 February 2010

Available online 21 February 2010

\section{Keywords:}

Membrane bioreactor

Solids residence time

Nitrification

Microbial ecology

\begin{abstract}
A B S T R A C T
Three submerged membrane bioreactors (MBRs) were operated continuously for 230 days by feeding with synthetic inorganic wastewater $\left(\mathrm{NH}_{4}^{+}-\mathrm{N}, 100 \mathrm{mgL}^{-1}\right)$ under different solids retention times (SRTs. $\mathrm{M}_{30 \mathrm{~d}}, 30$ days; $\mathrm{M}_{90 \mathrm{~d}}, 90$ days; $\mathrm{M}_{\text {infinite, }}$, no sludge purge) to examine the influence of SRT on nitrification performance and microbial characteristics. All the reactors could oxidize $\mathrm{NH}_{4}^{+}-\mathrm{N}$ to $\mathrm{NO}_{3}^{-}-\mathrm{N}$ effectively without accumulation of $\mathrm{NO}_{2}^{-}-\mathrm{N} . \mathrm{M}_{30 \text { d }}$ with the shortest SRT showed significantly higher specific ammonium oxidizing rate (SAOR, $0.22 \mathrm{~kg}$ $\mathrm{NH}_{4}^{+}-\mathrm{N} \mathrm{kg}^{-1} \mathrm{MLSS}$ day $^{-1}$ ) and specific nitrate forming rate (SNFR, $0.13 \mathrm{~kg} \mathrm{NO} \mathrm{NO}_{3}^{-} \mathrm{N} \mathrm{kg}^{-1}$ MLSS day ${ }^{-1}$ ) than the other two MBRs $\left(0.12-0.14 \mathrm{~kg} \mathrm{NO}_{3}^{-}-\mathrm{N} \mathrm{kg}^{-1} \mathrm{MLSS}^{-1}{ }^{-1}\right.$ and $0.042-$ $0.068 \mathrm{~kg} \mathrm{NO}_{3}^{-}-\mathrm{N} \mathrm{kg}^{-1} \mathrm{MLSS}$ day $^{-1}$, respectively). Short SRT led to low extracellular polymeric substances (EPS) concentration and long operating cycle. The nitrite oxidizing bacteria (NOB) ratios by both the fluorescence in situ hybridization (FISH) (3.6\% for $\mathrm{M}_{30 \mathrm{~d}}$ and 2.1-2.2\% for $\mathrm{M}_{90 \mathrm{~d}}$ and $\left.\mathrm{M}_{\text {infinite }}\right)$ and MPN $\left(1.4 \times 10^{7}\right.$ cells g ${ }^{-1}$ MLSS for $\mathrm{M}_{30 \mathrm{~d}}$ and $6.2 \times 10^{5}$ and $2.7 \times 10^{4}$ cells $^{-1}$ MLSS for $\mathrm{M}_{90 \mathrm{~d}}$ and $\mathrm{M}_{\text {infinite}}$ ) analyses showed that $\mathrm{M}_{30 \mathrm{~d}}$ favored the accumulation of NOB, which was in accordance with the SNFR result. However, the ammonia oxidizing bacteria (AOB) ratios (3.5\%, 3.2\% and $4.9 \%$ for $\mathrm{M}_{30 d}, \mathrm{M}_{90 \mathrm{~d}}$ and $\mathrm{M}_{\text {infinite }}$ ) were not in accordance with the SAOR result. PCR-DGGE, clone library and FISH results showed that the fast-growing Nitrosomonas and Nitrobacter sp. were the dominant $A O B$ and NOB, respectively for $\mathrm{M}_{30 \mathrm{~d}}$, while considerable slow-growing Nitrosospira and Nitrospira sp. existed in $\mathrm{M}_{\text {infinite, which }}$ might be an important reason why $\mathrm{M}_{\text {infinite }}$ had a low SAOR and SNFR.
\end{abstract}

(๖) 2010 Elsevier Ltd. All rights reserved.

\section{Introduction}

The most important point of membrane bioreactors (MBRs) is that this technology permits biological wastewater treatment under desirable solids residence times (SRTs), which allows the systems to keep a sufficient amount of slow-growing microbes, such as ammonia oxidizing bacteria (AOB) and those specializing in degrading refractory compounds, by choosing a relatively long SRT (Stamper et al., 2003; Xing et al., 2000). A long SRT, at the same time, will permit a stable treatment and low excess sludge production (Fan et al., 2005; Howell et al., 2003). The higher biomass concentration also increases shock tolerance, which is particularly important where feed is highly variable (Bin et al., 2009). However, too long an SRT may result in membrane fouling due to the accumulation of large amount of EPS in the MBR systems (Djamila et al., 2008). How to choose a proper SRT to achieve high water quality while prevent serious membrane fouling is therefore an important issue for the operation of MBRs.

\footnotetext{
* Corresponding author. Tel.: +8610 62923475; fax: +861062923541.

E-mail address: yangmin@rcees.ac.cn (M. Yang). 
On the other hand, activated sludge is a complicated ecological system where different types of microbes cooperate or compete with each other. Our previous study has shown that a large amount of heterotrophic bacteria coexisted with AOB and nitrite oxidizing bacteria (NOB) even in an MBR fed with inorganic ammonia-bearing wastewater (Hongyan et al., 2005b). It was considered that these heterotrophs live mainly on EPS and dead AOB and NOB. Different microbes have different growth rates. Therefore, the selection of SRT may affect microbial community structures as well as bioactivities in the biological systems.

It is considered that almost no excess sludge will be generated if an MBR is operated without sludge purge. However, it is not known if such an operation mode will adversely affect the bioactivity and performance of the MBR system. So in the present study, three reactors $\left(\mathrm{M}_{30 \mathrm{~d}}, \mathrm{M}_{90 \mathrm{~d}}\right.$ and $\mathrm{M}_{\text {infinite}}$ ) fed with inorganic ammonia-bearing wastewater were established, and the reactor performance, bioactivity and microbial community structures of the MBRs were investigated under different SRTs ( $\mathrm{M}_{30 d}, 30$ days; $\mathrm{M}_{90 \mathrm{~d}}, 90$ days; $\mathrm{M}_{\text {infinite, }}$, no sludge purge) for 230 days.

\section{Materials and methods}

\subsection{Experimental system}

Fig. 1 shows the schematic diagram of the experimental system consisting of three identical MBRs $\left(\mathrm{M}_{30 \mathrm{~d}}-\mathrm{M}_{\text {infinite }}\right)$. A submerged hollow fiber membrane module (Mitsubishi Rayon Co. Ltd., Tokyo) with an average pore size of $0.4 \mu \mathrm{m}$ and surface area of $0.2 \mathrm{~m}^{2}$ was used for each MBR. The working volume of each reactor was $12 \mathrm{~L}$ and the HRT was controlled at $16 \mathrm{~h}$. Air was supplied at a rate of $1 \mathrm{~L} \mathrm{~min}^{-1}$ to maintain dissolved oxygen (DO) at $3-5 \mathrm{mg} \mathrm{L}^{-1}$. The $\mathrm{pH}$ in the three reactors was 7.5-8.0 and the temperature was kept at $20 \pm 1^{\circ} \mathrm{C}$. The permeate flux was suctioned by a metric pump controlled with a timer (Hongyan et al., 2005a). The operational cycle included 4 min of suction and 1 min break. $\mathrm{M}_{30 d}$ and $\mathrm{M}_{90 d}$ were operated at an SRT of 30 days and 90 days, respectively, and $\mathrm{M}_{\text {infinite }}$ was operated without sludge purging. The three systems were operated in parallel for 230 days. The membranes were rinsed with water when the operating pressure suddenly increased.

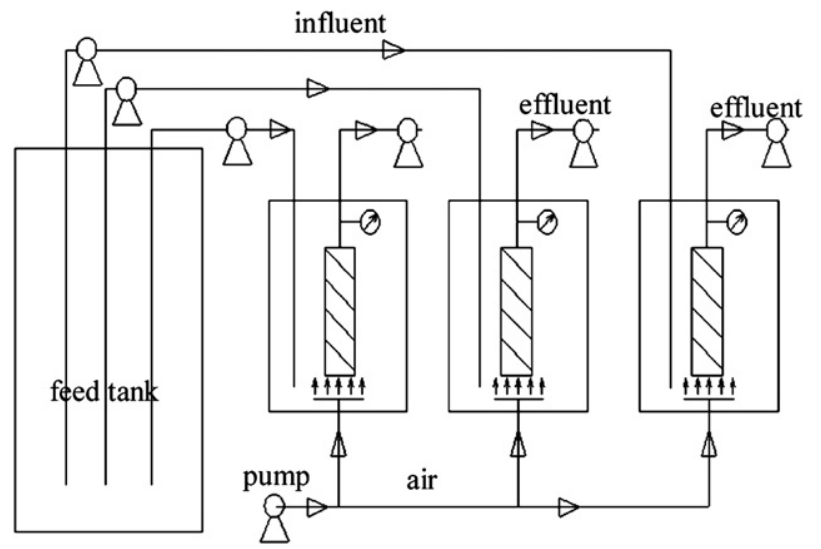

Fig. 1 - Schematic diagram of membrane reactors.
Seed sludge was taken from one sewage treatment plant in Beijing, and inoculated to MBRs with an average MLSS of $4300 \mathrm{mg} \mathrm{L}^{-1}$. Synthetic inorganic wastewater (Hongyan et al., 2005a) with an influent $\mathrm{NH}_{4}^{+}-\mathrm{N}$ of approximately $100 \mathrm{mg} \mathrm{L}^{-1}$ was fed to the MBRs soon after the inoculation of seed sludge to give a volumetric loading rate of $0.15 \mathrm{~kg} \mathrm{NH}_{4}^{+}-\mathrm{N} \mathrm{m}^{-3}$ day ${ }^{-1}$. Influent and effluent samples were take from each reactor to analyze $\mathrm{NH}_{4}^{+}-\mathrm{N}, \mathrm{NO}_{2}^{-}-\mathrm{N}, \mathrm{NO}_{3}^{-}-\mathrm{N}$ and $\mathrm{EPS}$, and sludge samples were taken to analyze MLSS, specific ammonium oxidizing rate (SAOR), specific nitrate forming rate (SNFR) and microbial community structures. SAOR and SNFR were used to determine the activities of activated sludge in oxidizing ammonia and nitrite, respectively. Detailed methods have been described previously (Hongyan et al., 2005a). EPS was extracted according to the methods proposed by Frolund et al. (1996). The content of polysaccharides was measured according to a phenol-sulphuric acid method and that of protein was determined with the Lowry method.

\subsection{Most probable number (MPN) enumeration and plate counting}

The MPN was used for the enumeration of $A O B$ and NOB, respectively, together with the FISH method (Hongyan et al., 2005a). $1 \mathrm{~mL}$ sample taken from a reactor was dispersed by sonication. Serial 10-fold dilutions of the inoculum sources were prepared in sterile distilled water and $1 \mathrm{~mL}$ portions were transferred to MPN tubes containing $9 \mathrm{~mL}$ of the enumeration medium. Five replicate tubes were prepared per dilution for enumeration. The MPN tubes were incubated for 30 days at $28^{\circ} \mathrm{C}$. Production and oxidization of nitrite in each tube were examined by colour determination after adding zinc powder and Griess reagent, respectively. The colony-forming unit (CFU) was used for the heterotrophs by depositing $0.1 \mathrm{~mL}$ serial dilutions on LB agar plates as inoculum. After incubating for $24 \mathrm{~h}$ under $37^{\circ} \mathrm{C}$, the numbers of the colonies on the plates were counted.

\subsection{FISH analysis}

Following sonication on ice for about $3 \mathrm{~min}$, activated sludge samples were fixed for $3 \mathrm{~h}$ with $4 \%$ paraformaldehyde at $4{ }^{\circ} \mathrm{C}$ and stored in a 1:1 mixture of phosphate-buffered saline (PBS, $\mathrm{pH}$ 7.4) and ethanol at $-20^{\circ} \mathrm{C}$ (Amann et al., 1995). $3 \mu \mathrm{L}$ samples were placed in wells of the slides and immobilized for $3 \mathrm{~h}$. Then the slides were dehydrated for 5 min using $50 \%, 80 \%$, $98 \%$ ethanol, respectively. The hybridization and washing procedures was the same with the protocol previously described by Amann et al. Fluorescent hybridized cells were analyzed with an epifluorescence microscope (Axioskop2 mot plus, Zeiss, Germany) equipped with a cooled CCD camera (AxioCam MRm, Zeiss Corp., Germany). The proportion of the nitrifiers was calculated with the software provided by Zeiss (Axio Vision 4.1). At least 40 views were obtained for each sample to give an average result.

Probes NSO190 (5'-CGA TCC CCT GCT TTT CTC C-3'), NIT3 (5'-CCT GTG CTC CAT GCT CCG-3') and EUB338 (5'-GCT GCC TCC CGT AGG AGT-3') were used for $\mathrm{AOB}, \mathrm{NOB}$ and active bacteria, respectively (Mobarry et al., 1996). 


\subsection{PCR-DGGE analysis}

A procedure described in a previous paper was adopted (Muyzer et al., 1993). DNA was extracted from $0.5 \mathrm{~mL}$ of mixed liquor samples. 16S rRNA gene fragments were amplified from the extracted total DNA from the samples with Taq DNA polymerase by using bacterial primer sets GC-341F (5'-CGC CCG CCG CGC CCC GCG CCC GTC CCG CCG CCC CCG CCC G-CCT ACG GGA GGC AGC AG-3') and 534R (5'-ATT ACC GCG GCT GCT GG-3'). The conditions used for the PCR were as follows: $5 \mathrm{~min}$ of initial denaturation at $94^{\circ} \mathrm{C}$ and 25 cycles of $30 \mathrm{~s}$ at $94^{\circ} \mathrm{C}, 30 \mathrm{~s}$ at $62.5^{\circ} \mathrm{C}$ and $40 \mathrm{~s}$ at $72{ }^{\circ} \mathrm{C}$, the annealing temperature was decreased by $0.3^{\circ} \mathrm{C}$ from $62.5^{\circ} \mathrm{C}$ to $65^{\circ} \mathrm{C}$ every cycle, followed by 10 cycles of $30 \mathrm{~s}$ at $94^{\circ} \mathrm{C}, 40 \mathrm{~s}$ at $55^{\circ} \mathrm{C}$ and $40 \mathrm{~s}$ at $72^{\circ} \mathrm{C}$. A final extension step was conducted at $72^{\circ} \mathrm{C}$ for $10 \mathrm{~min}$ prior to cooling at $4{ }^{\circ} \mathrm{C}$.

The AOB DNA fragments of $465 \mathrm{bp}$ in length were acquired using a specific primer pair of two forward primers CTO189fA/ B-GC (5'-CCG CCG CGC GGC GGG CGG GGC GGG GGC ACG GGG GGA GRA AAG CAG GGG ATC G-3') and CTO189fC-GC (5'-CGC CCG CCG CGC GGC GGG CGG GGC GGG GGC ACG GGG GGA GGA AAG TAG GGG ATC G-3') in a ratio of 2:1, and a reverse primer CTO654r (5'-CTA GCY TTG TAG TTT CAA ACG C-3'). The PCR condition was as follows: $95^{\circ} \mathrm{C}$ for $5 \mathrm{~min}$ followed by 35 cycles of $45 \mathrm{~s}$ at $94^{\circ} \mathrm{C}, 45 \mathrm{~s}$ at $57^{\circ} \mathrm{C}, 45 \mathrm{~s}$ at $72{ }^{\circ} \mathrm{C}$, and a final extension of $10 \mathrm{~min}$ at $72^{\circ} \mathrm{C}$. All the PCR products were electrophoresed on a $1 \%$ agarose gel.

DGGE was performed by using a Dcode system (Bio-Rad Co., USA). The PCR-amplified DNA fragments were separated on polyacrylamide gels $(10 \%$, acrylamide:bisacrylamide $=37.5: 1)$ in $1 \times$ TAE buffer $(20 \mathrm{mM}$ Tris-acetate, $10 \mathrm{mM}$ sodium acetate, $0.5 \mathrm{mM}$ EDTA, $\mathrm{PH}$ 7.4) with a denaturing gradient ranging from $35 \%$ to $55 \%$. Electrophoresis was initially run for $30 \mathrm{~min}$ at $60 \mathrm{~V}$ and subsequently for $8 \mathrm{~h}$ at $120 \mathrm{~V}$. Then, the gel was soaked for $30 \mathrm{~min}$ in ethidium bromide and photographed on a UV transillumination table with a Gel Documentation Systems (BIO-RAD Laboratories-Segrate, Milan, Italy). The images were analyzed with Quantity One Software (Bio-Rad, USA). Prominent bands were excised and put in $50 \mu \mathrm{L}$ sterilized water at $4{ }^{\circ} \mathrm{C}$ overnight. $5 \mu \mathrm{L}$ of the eluate was used as template DNA for a PCR performed with the primers $534 \mathrm{R}$ and $341 \mathrm{~F}$ without GC clamp, and conditions described above for environmental samples. The remaining PCR products were sequenced with an ABI 3730 automated sequencer (Invitrogen, Shanghai, China).

The obtained DGGE patterns were subsequently analyzed with the BioNumerics software version 6.0 (Applied Maths, Kortrijk, Belgium). During this processing, different lanes were defined, the background was subtracted, differences in the intensity of the lanes were compensated, and the correlation matrix was calculated. Clustering was done with Pearson correlation and the UPGMA method (Possemiers et al., 2004). The correlation between day $\mathrm{x}$ and day $\mathrm{x}-30$ was plotted for day $50,80,110,140,170,200$ and 230 to evaluate the community stability within the groups of $\mathrm{AOB}$ and general bacteria in reactors $\mathrm{M}_{30 d}, \mathrm{M}_{90 \mathrm{~d}}$ and $\mathrm{M}_{\text {infinite }}$ using the principle of moving window correlation.

\subsection{Clone library construction}

The total extracted DNA was used as the DNA template in the PCR reaction with the primer amoA1f (5'-GGG GTT TCT ACT
GGT GGT-3') and amoA2r (5'-CCC CTC (C/T)G (G/C)A AAG CCT TCT TC- $\left.3^{\prime}\right)$. Primers amoA1f and amoA2r were used to amplify a 491-bp fragment of the amoA gene, according to the protocol described by You and Chen (2008). The PCR products were then used for cloning, in accordance with the manufacturer's protocol (TA cloning kit, Invitrogen). Colonies with the correct inserts were then screened using PCR with another plasmidvector specific primers M13f and $\mathrm{M} 13 \mathrm{r}\left(95^{\circ} \mathrm{C}\right.$ for $1 \mathrm{~min}$, followed by 30 cycles of denaturation at $95^{\circ} \mathrm{C}$ for $90 \mathrm{~s}$, annealing at $47^{\circ} \mathrm{C}$ for $45 \mathrm{~s}$ and extension at $72^{\circ} \mathrm{C}$ for $2 \mathrm{~min}$, and to be completed after $5 \mathrm{~min}$ at $72^{\circ} \mathrm{C}$ ). The positive amoA PCR products were then used for screening the genetic diversity by using restriction fragment length polymorphism (RFLP) screening with HaeIII (GG'CC) restriction enzyme digestion reactions (mixed with $10 \mu \mathrm{L}$ of the PCR product, $1 \mu \mathrm{L}$ of each restriction enzyme (10 units per $\mu \mathrm{L}$ ), $2 \mu \mathrm{L}$ of $10 \times$ buffer and $7 \mu \mathrm{L}$ of $\mathrm{dd}_{2} \mathrm{O}$, at $37^{\circ} \mathrm{C}$ for $6 \mathrm{~h}$ ). Positive clones were sequenced with an $\mathrm{ABI}$ 3730 automated sequencer (Invitrogen, Shanghai, China).

\subsection{Phylogenetic analysis}

After editing and trimming manually using BioEdit, bacterial 16S rRNA gene and amoA gene sequences obtained in this study were searched against the GenBank database using the BLASTN program (Altschul et al., 1997). The most similar reference sequences were retrieved and aligned with the sequences of this study using CLUSTALX (Thompson et al., 1997). Phylogenetic trees were constructed using MEGA version 4 by the neighbour-joining algorithm and the JukesCantor distance estimation method with bootstrap analyses for 1000 replicates (Kumar et al., 2004).

\subsection{Nucleotide sequence accession numbers}

The 16S rRNA nucleotide sequences as well as amoA gene sequences of this study were deposited in the GenBank database under the accession numbers GU121104-GU121133, GU121134-GU121151, respectively.

\section{Results and discussion}

\subsection{Reactor performance}

Because of the relatively low volumetric loading rate $\left(0.15 \mathrm{~kg} \mathrm{NH}_{4}^{+}-\mathrm{N} \mathrm{m}^{-3}\right.$ day $\left.^{-1}\right)$, all of the three MBRs showed stable nitrification performance, the effluent $\mathrm{NH}_{4}^{+}-\mathrm{N}$ and $\mathrm{NO}_{2}^{-}-\mathrm{N}$ were generally below $1.0 \mathrm{mgL}^{-1}$ and $0.5 \mathrm{mgL}^{-1}$, and the average effluent $\mathrm{NO}_{3}^{-}-\mathrm{N}$ concentrations of $\mathrm{M}_{30 \mathrm{~d}}, \mathrm{M}_{90 d}$ and $\mathrm{M}_{\text {infinite }}$ were $96.8 \mathrm{mgL}^{-1}, 93.7 \mathrm{mgL}^{-1}$ and $94.8 \mathrm{mg} \mathrm{L}^{-1}$, respectively. Fig. 2(a)(c) show the changes of MLSS, EPS and transmembrane pressure (TMP) of the three reactors, respectively. The three reactors began to show significant differences in biomass concentration soon after the start of the experiment, and the average MLSS values of $\mathrm{M}_{30 \mathrm{~d}}, \mathrm{M}_{90 \mathrm{~d}}$ and $\mathrm{M}_{\text {infinite }}$ were $1354 \mathrm{mgL}^{-1}, 3131 \mathrm{mgL}^{-1}$ and $4897 \mathrm{mgL}^{-1}$, respectively, from day 60 . The MLSS values of $M_{\text {infinite }}$ were in accordance with our previous results acquired with an $\mathrm{NH}_{4}^{+}-\mathrm{N}$-feeding MBR operated without sludge purge (5000 $\mathrm{mgL}^{-1}$. Mengchun et al., 2004), but were significantly lower than those acquired for MBRs fed 


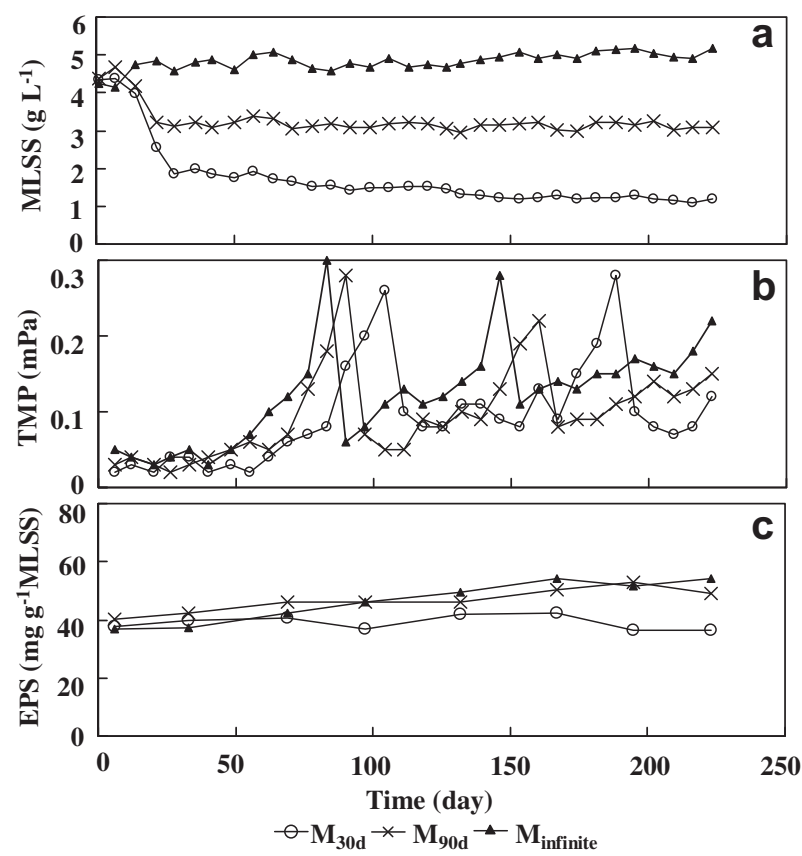

Fig. 2 - (a) The changing course of MLSS of the three MBRs. (b) The operation pressure of three MBRs (c) Change of EPS in the MBRs.

on organic wastewater without sludge purge $(18,000-$ 20,000 $\mathrm{mg} \mathrm{L}^{-1}$. Darren et al., 2006; Rosenberger et al., 2002).

As shown in Fig. 2(b), a sudden increase of operating pressures appeared due to the accumulation of sludge on the membrane surface after the reactors were run for several months. The filtration performance of the membranes was recovered after sludge on the surface was removed physically in clean water. The length of the first cycle was 105 days, 90 days and 83 days, respectively, for $\mathrm{M}_{30 \mathrm{~d}}-\mathrm{M}_{\text {infinite, }}$ and that for the second cycle was 88 days, 72 days and 63 days, showing that long SRTs led to short operating cycles.

It has been reported that EPS consisting of polysaccharides and proteins was a key factor for membrane pollution in MBRs (Lee et al., 2003). It was observed that the amount of EPS per unit of biomass with MBR was approximately $30-80 \mathrm{mg} \mathrm{g}^{-1}$ MLSS in some studies (Ahmed et al., 2007; Fangang et al., 2006; How et al., 2005). Our previous results (Mengchun et al., 2004) showed EPS in MBR increased from 20 to $160 \mathrm{mg} \mathrm{g}^{-1}$ MLSS under different volumetric loading rate $\left(0.18-1.30 \mathrm{~kg} \mathrm{NH}_{4}^{+}\right.$ $\mathrm{N} \mathrm{m}^{-3}$ day $^{-1}$ ). The EPS levels in this study were within the above reported ranges: the EPS levels in $\mathrm{M}_{90 d}$ and $\mathrm{M}_{\text {infinite }}$ increased slowly from 40 to $55 \mathrm{mg} \mathrm{g}^{-1}$ MLSS, while that in $\mathrm{M}_{30 \mathrm{~d}}$ remained a constant value of $40 \mathrm{mg} \mathrm{g}^{-1}$ MLSS. The relatively low EPS level in $\mathrm{M}_{30 \mathrm{~d}}$ might be related with its relatively long operating cycle.

\subsection{Bioactivity}

Fig. 3 shows that the values of SAOR and SNFR in all of the three reactors did not change much for the duration of 230 days. It is clear that the bioactivities of the MBRs were affected by SRT markedly. $\mathrm{M}_{30 \text { d }}$ with the shortest SRT showed the highest average SAOR $\left(0.22 \mathrm{~kg} \mathrm{NH}_{4}^{+}-\mathrm{N} \mathrm{kg}^{-1} \mathrm{MLSS}_{\text {day }}{ }^{-1}\right)$ and SNFR $\left(0.13 \mathrm{~kg} \mathrm{NO}_{3}^{-}-\mathrm{N} \mathrm{kg}^{-1} \mathrm{MLSS}^{-1} \mathrm{day}^{-1}\right)$ among the three MBRs.
While $\mathrm{M}_{90 \mathrm{~d}}$ and $\mathrm{M}_{\text {infinite }}$ showed a similar SAOR value (0.12-0.14 kg NH$+4 \mathrm{~kg}^{-1}$ MLSS day ${ }^{-1}$ ), their SNFR values were different (0.068 and $0.042 \mathrm{~kg} \mathrm{NO}_{3}^{-}-\mathrm{N} \mathrm{kg}^{-1} \mathrm{MLSS}_{\text {day }}{ }^{-1}$ ).

\subsection{FISH and cell number counting}

Probes EUB338, NSO190 and NIT3 were used for the detection of bacteria, AOBs in the $\beta$ subclass of Proteobacteria (including Nitrosomonas, Nitrosococcus mobilis, Nitrosospira, Nitrosovibrio and Nitrosolobus) (Purkhold et al., 2000; Hesselsoe et al., 2001; Persson et al., 2002) and Nitrobacter sp., respectively, and the results are shown in Fig. 4. Fig. 4(c) shows the changes of the ratio of active bacteria (specific to probe EUB) to total microbes (DAPI stained particles). The EUB/DAPI ratios in all of the three MBRs decreased with the increase of operation time, possibly due to the accumulation of inactive substances in the MBRs. In comparison with $\mathrm{M}_{90 d}$ and $\mathrm{M}_{\text {infinite }}$ where the EUB/DAPI ratio decreased from $56 \%$ to $28 \%, \mathrm{M}_{30 \mathrm{~d}}$ showed a relatively high active bacterial percentage (from $56 \%$ to $42 \%$ ). As shown in Fig. 4(a), the AOB/DAPI values varied in a relatively wide range, suggesting some inaccuracy in detecting AOBs with the FISH technique. Despite this, however, it is still clear that the AOB/ DAPI ratio in $\mathrm{M}_{\text {infinite }}$ was much higher than those in the other two systems (the average ratios were $3.5 \%, 3.2 \%$ and $4.9 \%$ for $\mathrm{M}_{30 \mathrm{~d}}, \mathrm{M}_{90 \mathrm{~d}}$ and $\mathrm{M}_{\text {infinite}}$ ), showing that no sludge purge strategy led to the increase of $A O B$ ratios. It is interesting why $M_{\text {infinite }}$ with the highest $A O B$ ratio showed the lowest ammonia oxidizing rate. On the other hand, as shown in Fig. 4(b), the NOB/DAPI ratios were quite stable from day 60 , with an average value of $3.6 \%$ in $\mathrm{M}_{30 \mathrm{~d}}$ contrast to $2.1-2.2 \%$ in the other two reactors, which was in accordance with the SNFR result. Since NIT3 was only sensitive to Nitrobacter sp., this result means that the short SRT in $\mathrm{M}_{30 \mathrm{~d}}$ favored the accumulation of the fast-growing NOB. The changes of the ratios of nitrifiers (the sum of AOBs and NOBs) to active bacteria (EUB) are shown in Fig. 4 (d). The nitrifier ratio in $\mathrm{M}_{\text {infinite }}$ increased from $5 \%$ to $25 \%$, while those in the other two MBRs increased from $5 \%$ to $15 \%$, showing that the nitrifier ratios significantly increased

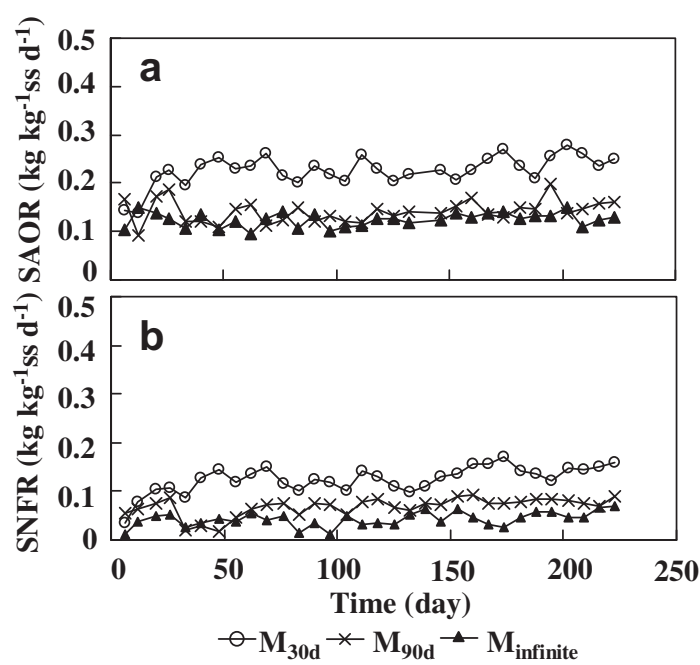

Fig. 3 - (a) The specific ammonium oxidizing rate (SAOR) of the three MBRs. (b) The specific nitrate forming rate (SNFR) of the three MBRs. 


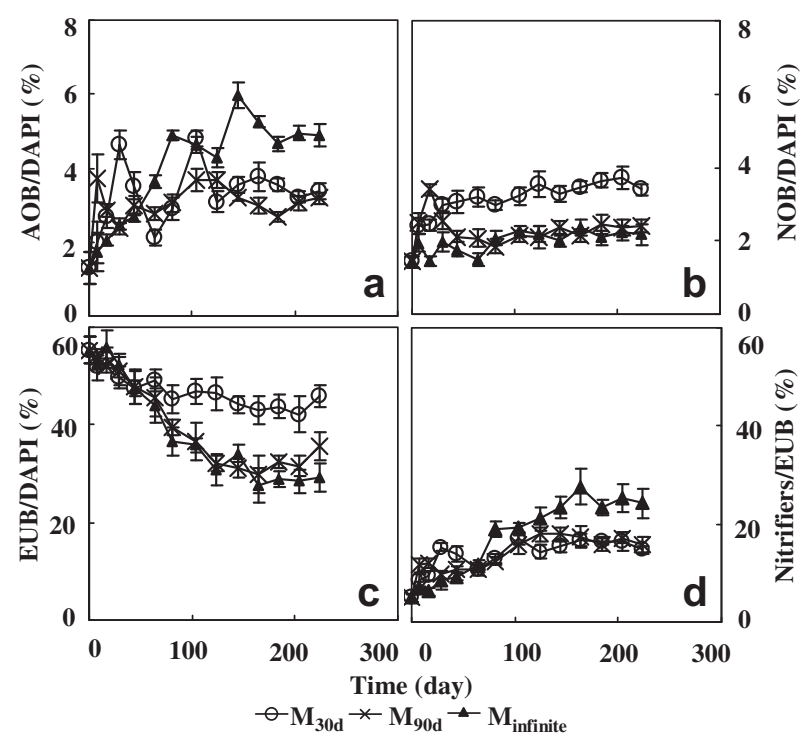

Fig. 4 - (a) Composition of AOB for probe NSO190. (b) Composition of NOB for probe NIT3. (c) Composition of active bacteria for probe EUB338. (d) Composition of Nitrifiers/EUB.

with the increase of operation time. But still, the majority of bacteria were heterotrophs.

At the same time, culture-based cell counts of $\mathrm{AOB}, \mathrm{NOB}$ (by MPN enumeration) and heterotrophs (by plate counting) were conducted on day 180 . The density of $A O B$ for $M_{30 d}-M_{\text {infinite }}$ was $1.6 \times 10^{7}, 3.4 \times 10^{7}$ and $1.5 \times 10^{7}$ cells g $^{-1}$ MLSS, respectively, that of NOB was $1.4 \times 10^{7}, 6.2 \times 10^{5}$ and $2.7 \times 10^{4}$ cells g $^{-1}$ MLSS, and that of heterotrophs was $0.8 \times 10^{8}, 1.2 \times 10^{7}$, $5.3 \times 10^{7}$ cells $g^{-1}$ MLSS. The culture-based result also showed that the ratio of NOB in $\mathrm{M}_{30 \mathrm{~d}}$ was higher than those of the other two reactors. Therefore, both the FISH and MPN results showed that shorter SRT resulted in a higher NOB density, which led to the higher SNFR. At the same time, the AOB ratio in $\mathrm{M}_{30 d}$ was in the same order with those in other two reactors. Together with the FISH result, it is speculated that the AOB species with lower bioactivities might have accumulated in $\mathrm{M}_{\text {infinite }}$ because of the extremely long SRT.

\subsection{PCR-DGGE}

16S rRNA gene fragments for bacteria and AOB were investigated by PCR-DGGE method. It is interesting that the bacterial communities in the three reactors kept changing in spite of the stable operating conditions and treatment performance during the period. In all of the three MBRs, the diversity of bacteria decreased with the increase of operation time, with $\mathrm{M}_{\text {infinite }}$ showing the highest diversity in the end (The $S$ values for $\mathrm{M}_{30 \mathrm{~d}}-\mathrm{M}_{\text {infinite }}: 0.39,0.43$ and 0.52). On the other hand, the $\mathrm{AOB}$ communities in the three reactors were relatively stable, with $\mathrm{M}_{\text {infinite }}$ showing the highest diversity.

All of the apparent bands were excised from the gels and sequenced, and a neighbour-joining tree, which graphically depicts the homologies of aligned sequences, was constructed for both bacteria and AOB as shown in Figs. 6 and 7. The three MBRs only shared one common bacterium (DM11, DM21, and
DM31 in Fig. 6) which was assigned to uncultured Acidobacteria bacterium. Bacteria in the phylum Acidobacteria are abundant in soils, and can be isolated from soils using low-nutrient medium (Stephanie et al., 2007). Although most of AOB are assigned to Nitrosomonas sp. for all of the three reactors, Nitrosospira sp. was also found in $\mathrm{M}_{\text {infinite }}$ with a bright band. On the other hand, although Nitrobacter sp. was found to exist in all of the three reactors abundantly by FISH, they were not detected in DGGE. We have not been able to identify Nitrobacter sp. in a previous study (Hongyan et al., 2005a,b), either. The bands related to Nitrospira sp. for NOB were found in $\mathrm{M}_{90 d}$ and $\mathrm{M}_{\mathrm{infinite}}$, but not in $\mathrm{M}_{30 \mathrm{~d}}$. It has been reported that Nitrospira sp. possessed a slow growing rate and a low $\mathrm{NO}_{2}^{-}-\mathrm{N}$ oxidizing rate (Magdalena et al., 2008; Okabe et al., 1999), while Nitrobacter sp. represent a fast growing rate and a high $\mathrm{NO}_{2}^{-}-\mathrm{N}$ oxidizing rate. Thus, the relatively low SNFR values with $\mathrm{M}_{90 d}$ and $\mathrm{M}_{\text {infinite }}$ might be attributed not only to the low NOB ratios, but also to the composition of NOB.

In the moving window correlation approach, the evolution of the similarity over time is depicted (Wittebolle et al., 2008; Marzorati et al., 2008). By plotting the correlation coefficients between day $\mathrm{x}$ and day $\mathrm{x}-30$ for each reactor against the time, graphical representations of the evolution of stability over time for $\mathrm{AOB}$ and general bacteria in the three MBRs were obtained (Fig. 5). The similarity of $A O B$ in $\mathrm{M}_{30 \mathrm{~d}}$ became relatively stable after reaching the lowest value of $38 \%$. On the other hand, the changes of $A O B$ similarity in $\mathrm{M}_{90 d}$ and $\mathrm{M}_{\text {infinite }}$ were quite similar: sharp decrease of the similarity value occurred on days 140 and 170, respectively. The above result can be explained by the differences of AOB community structures: the fast-growing Nitrosomonas sp. grew quickly and became the dominant $A O B$ with a relatively short period in $\mathrm{M}_{30 \mathrm{~d}}$, while in $\mathrm{M}_{\text {infinite }}$ and perhaps $\mathrm{M}_{90 \mathrm{~d}}$, it took a much longer

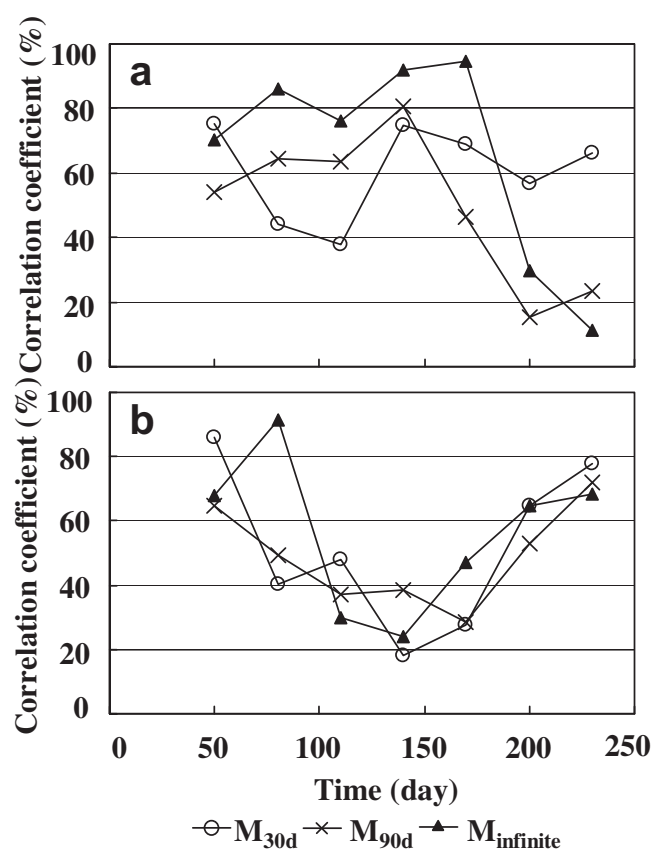

Fig. 5 - Moving window correlation for reactors $\mathbf{M}_{\mathbf{3 0 d}}, \mathbf{M}_{\mathbf{9 0 d}}$ and $\mathbf{M}_{\text {infinite. }}$ Variability between day $\mathbf{x}$ and day $\mathbf{x}-30$ was calculated from DGGE patterns of AOB (a) and general bacteria (b). 


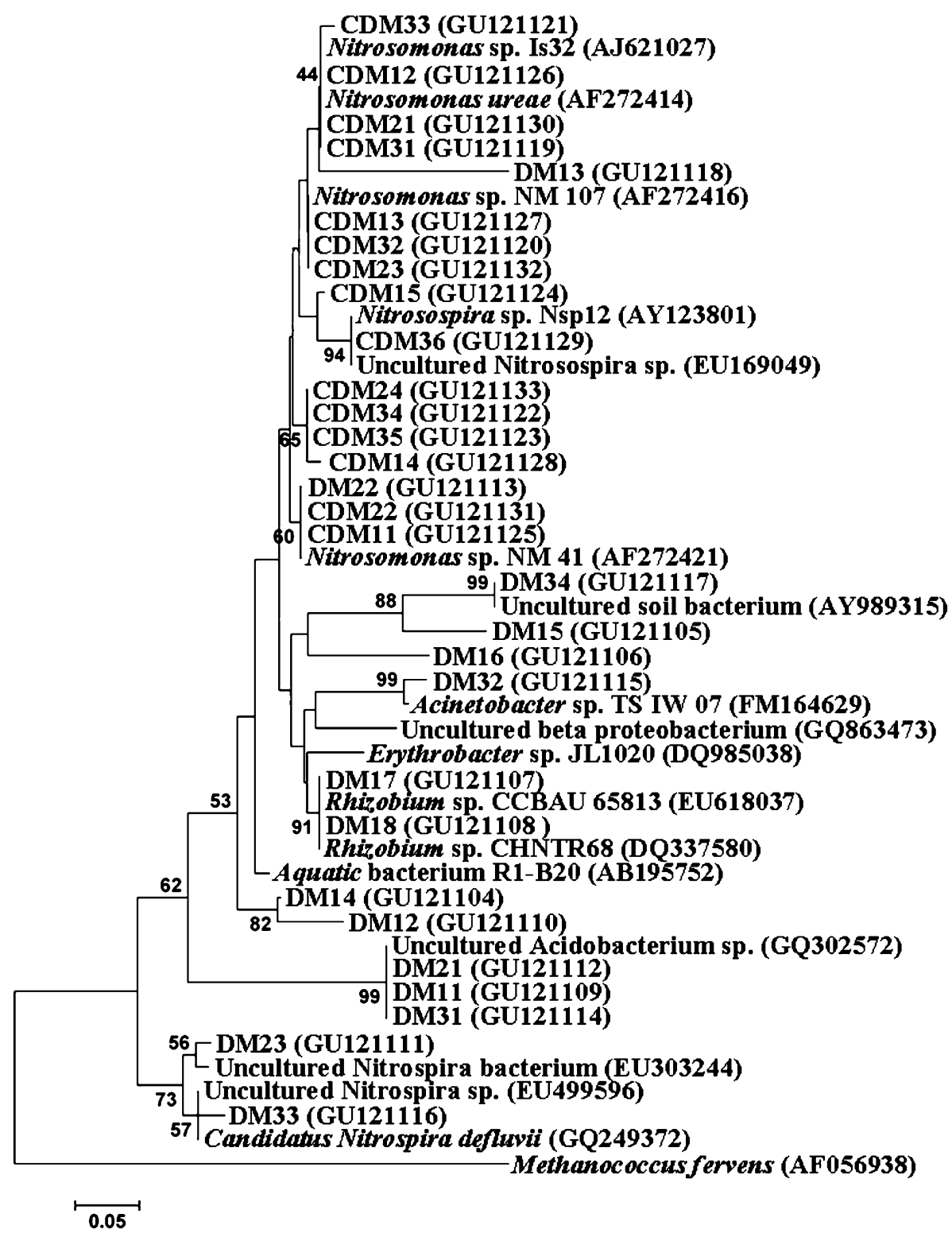

Fig. 6 - Neighbour-joining tree of partial 16S rRNA sequences recovered from samples with three MBRs using bacterial primers (DM11-DM18 for $\mathbf{M}_{30 d}$, DM21-DM23 for $\mathbf{M}_{90 d}$ and DM31-DM34 for $\mathbf{M}_{\text {infinite) and CTO primers (CDM11-CDM15 for }}$

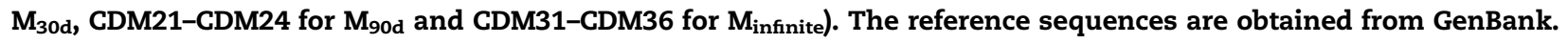
GenBank accession numbers are in parentheses.

time for the slowly-growing Nitrosospira sp. to become dominant. For general bacteria, on the other hand, the changes of similarity of the three reactors were almost the same: the similarity decreased at first, and then increased. This result shows that in spite of the differences of the community structures of AOBs, the three MBRs possibly possessed similar heterotrophic community structures.

\subsection{Clone libraries of amoA gene}

In order to get more detailed information regarding $A O B$ community diversity in MBRs, three amoA gene clone libraries were constructed for the three MBR reactors. 30-60 clones were selected and processed by RFLP for each library, at least one clone of each pattern was sequenced and 40 sequences were totally acquired for the three MBR reactors ( 14 for $M_{30 d}, 9$ for $\mathrm{M}_{90 d}$ and 17 for $\left.\mathrm{M}_{\text {infinite}}\right)$. All bacteria from the cloned libraries were classified into Nitrosomonas sp. and Nitrosospira sp. which both belong to the Betaproteobacteria (Fig. 7) and are important AOB in activated sludge systems (Dytczak et al., 2008). However, the distribution of them in three MBRs was quite different. The Nitrosomonas sp. comprised of $89 \%$ of the clones in $\mathrm{M}_{30 \mathrm{~d}}$ library, $100 \%$ in $\mathrm{M}_{90 \mathrm{~d}}$ library, and $57 \%$ in $\mathrm{M}_{\text {infinite }}$ library. Meanwhile, $11 \%$ of the total clones in $\mathrm{M}_{30 \mathrm{~d}}$ and $43 \%$ of the clones in $\mathrm{M}_{\text {infinite }}$ library were affiliated with Nitrosospira sp. bacteria.

The Nitrosomonas and Nitrobacter sp., growing quickly with high concentrations of substrates, are two classic nitrifiers commonly used in engineering texts to describe ammonia and 


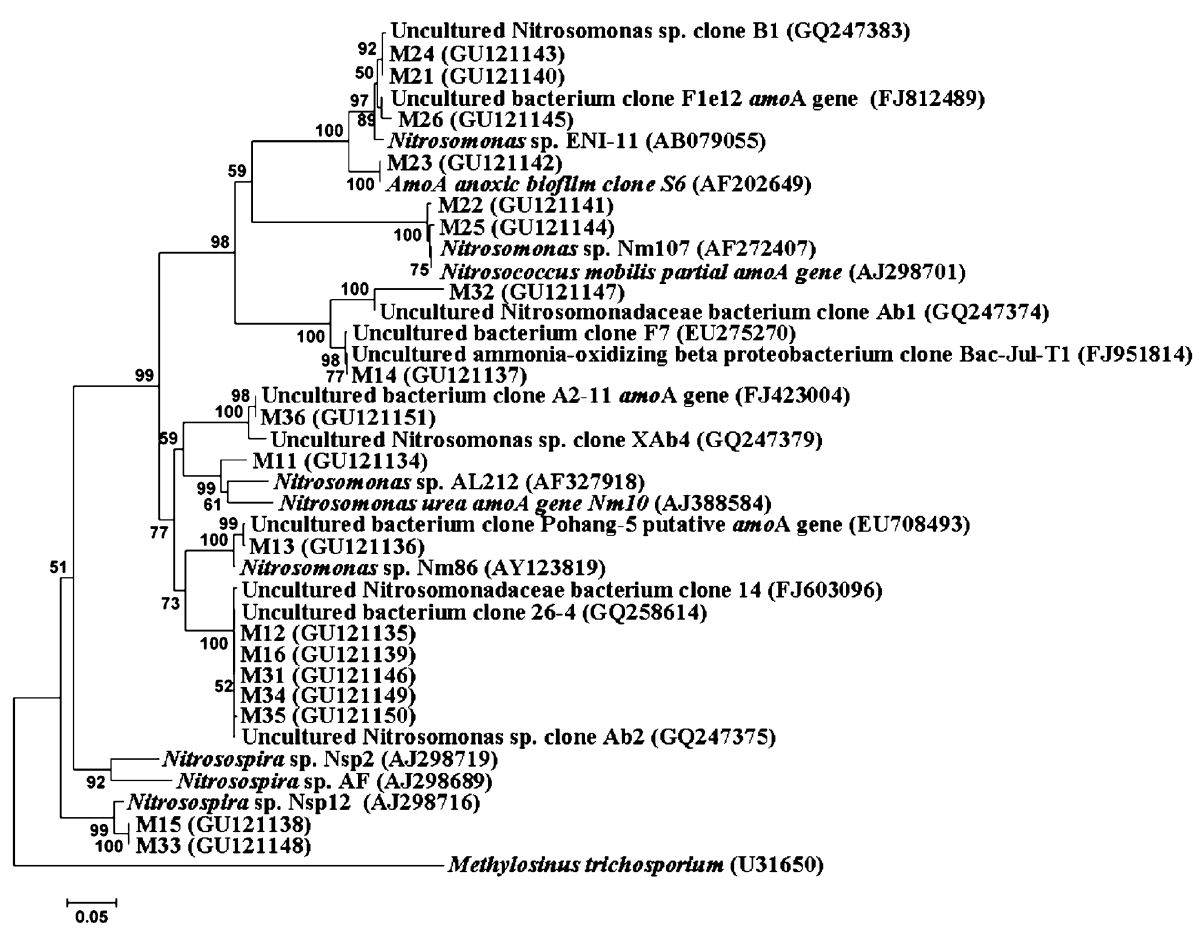

Fig. 7 - Neighbour-joining tree of partial amoA sequences recovered from samples with three MBRs using amoA primers. Bootstrap values (based on 1000 replicates) are given at nodes when they exceed $50 \%$ of replicates. The reference sequences

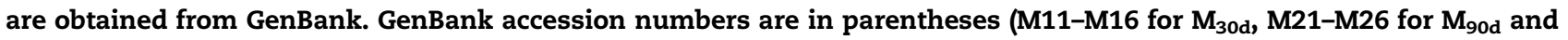
M31-M36 for $\mathbf{M}_{\text {infinite). }}$

nitrite oxidation, respectively (Stehr et al., 1995). In contrast, the Nitrosospira and Nitrospira sp. can survive longer periods of starvation, due to their slower rates (Schramm et al., 1999). It has been reported that in winter when the temperature was below the optimum range for nitrifier growth and the SRT was long, Nitrosospira thrived better in municipal wastewater treatment plants (Siripong and Rittmann, 2007). Due to the extremely long SRT, Nitrosospira sp. accumulated in $\mathrm{M}_{\text {infinite, }}$ resulting in the high $A O B$ ratio. This is why $M_{\text {infinite }}$ showed the lowest $\mathrm{SAOR}$ in spite of its high AOB ratio. The relatively low density of $A O B$ in $M_{\text {infinite }}$ by the MPN method was perhaps related with the significant presence of the slow-growing Nitrosospira sp. No Nitrosospira sp. was detected in $\mathrm{M}_{90 d}$, perhaps due to the fewer sequence number obtained and the relatively low Nitrosospira ratio in the system.

\section{Conclusions}

The impacts of SRT on reactor performance and microbial community structures of MBRs were investigated and the following conclusions were acquired.

1. Purge of activated sludge at a proper interval permitted higher ammonia and nitrite oxidation rates and lower EPS concentrations.

2. MBR with the shortest SRT (30 days) had the highest NOB ratio while that with the longest SRT (no purge of sludge) had the highest AOB ratio.

3. The fast-growing Nitrosomonas and Nitrobacter sp. bacteria were the dominant $\mathrm{AOB}$ and $\mathrm{NOB}$, respectively in the MBR with the shortest SRT, while considerable slow-growing Nitrosospira and Nitrospira sp. bacteria existed in the MBR with the longest SRT.

\section{Acknowledgements}

The authors appreciate financial support for this work provided by the Ministry of Sciences and Technology (2006DFA91870), the National Natural Science Foundation of China (20921140094, 50921064), and Chinese Academy of Sciences (KSCX2-YW-G-054).

\section{Appendix. Supplementary data}

Supplementary data associated with this article can be found in the online version, at doi:10.1016/j.watres.2010.02.021.

\section{R E F E R E N C E S}

Ahmed, Z., Cho, J., Lim, B.R., Song, K.G., Ahn, K.H., 2007. Effects of sludge retention time on membrane fouling and microbial community structure in a membrane bioreactor. J. Memb. Sci. 287 (2), 211-218.

Altschul, S.F., Madden, T.L., Schäffer, A.A., Zhang, J., Zhang, Z., Miller, W., Lipman, D.J., 1997. Gapped BLAST and PSI-BLAST: a new generation of protein database search programs. Nucleic Acids Res. 25, 3389-3402. 
Amann, R.I., Ludwin, W., Schleifer, K.H., 1995. Phylogenetic identification and in situ detection of individual microbial cells without cultivation. Microbiol Rev. 59, 143-169.

Bin, Z., Baosheng, S., Min, J., Huina, L., 2009. Population dynamic succession and quantification of ammonia-oxidizing bacteria in a membrane bioreactor treating municipal wastewater. J. Hazard. Mater. 165, 796-803.

Darren, D.S., Choon, T.H., Swee, L.K., 2006. Effects of hydraulic retention time on behavior of start-up submerged membrane bioreactor with prolonged sludge retention time. Desalination 195, 209-225.

Djamila, A.H., Jacqueline, T., Sven, L., Thomas, W., Thomas, M., Daniela, T., Andreas, J., Wolfgang, D., Juliane, H., 2008. Correlation of EPS content in activated sludge at different sludge retention times with membrane fouling phenomena. Water Res. 42, 1475-1488.

Dytczak, A.M., Londry, L.K., Oleszkiewicz, A.J., 2008. Activated sludge operational regime has significant impact on the type of nitrifying community and its nitrification rates. Water Res. 42, 2320-2328.

Fan, F., Zhou, H., Husain, H., 2005. Identification of wastewater sludge characteristics to predict critical flux for membrane bioreactor processes. Water Res. 40 (2), 205-212.

Fangang, M., Fenglin, Y., Jingni, X., Hanmin, Z., Zheng, G., 2006. A new insight into membrane fouling mechanism during membrane filtration of bulking and normal sludge suspension. J. Memb. Sci. 285, 159-165.

Frolund, B., Palmgren, R., Keiding, K., Nielsen, P.H., 1996. Extraction of extracellular polymers from activated sludge using a cation exchange resin. Water Res. 30 (8), 1749-1758.

Hesselsoe,, M., Brandt, K.K., Sorensen, J., 2001. Quantification of ammonia oxidizing bacteria in soil using microcolony technique combined with fluorescence in situ hybridization (MCFU-FISH). FEMS Microbiol. Ecol. 38, 87-95.

Hongyan, L., Min, Y., Yu, Z., Tao, Y., Yoichi, K., 2005a. Nitrification performance and microbial community dynamics in a submerged membrane bioreactor with complete sludge retention. J. Biotechnol. 123 (1), 60-70.

Hongyan, L., Min, Y., Yu, Z., Xinchun, L., Mengchun, G., Yoichi, K., 2005b. Comparison of nitrification performance and microbial community between submerged membrane bioreactor and conventional activated sludge system. Water Sci. Technol. 51 (6-7), 535-543.

How, Y.N., Slawomir, W., Hermanowicz, 2005. Membrane bioreactor operation at short solids retention times: performance and biomass characteristics. Water Res. 39, 981-992.

Howell, J.A., Arnot, T.C., Liu, W., 2003. Membrane bioreactors for treating waste streams. Ann. N.Y. Sci. 984, 411-419.

Kumar, S., Tamura, K., Nei, M., 2004. MEGA3: integrated software for molecular evolutionary genetics analysis and sequence alignment. Brief Bioinform. 5, 150-163.

Lee, W., Kang, S., Shin, H., 2003. Sludge characteristics and their contribution to microfiltration in submerged membrane bioreactors. J. Memb. Sci. 216, 217-227.

Magdalena, A.D., Kathleen, L.L., Jan, A.O., 2008. Activated sludge operational regime has significant impact on the type of nitrifying community and its nitrification rates. Water Res. 42 , 2320-2328.

Marzorati, M., Wittebolle, L., Boon, N., Daffonchio, D., Verstraete, W., 2008. How to get more out of molecular fingerprints: practical tools for microbial ecology. Environ. Microbiol. 10 (6), 1571-1581.

Mengchun, G., Min, Y., Hongyan, L., Qingxiang, Y., Yu, Z., 2004. Nitrification and sludge characteristics in a submerged membrane bioreactor on synthetic inorganic wastewater. Desalination 170, 177-185.

Mobarry, B.K., Wagner, M., Urbain, V., Rittmann, B.E., Stahl, D.A., 1996. Phylogenetic probes for analyzing abundance and spatial organization of nitrifying bacteria. Appl. Environ. Microbiol. 62 (6), 2156-2162.

Muyzer, G., Waal, E.C.D., Uitterlinden, A.G., 1993. Profiling of complex microbial populations by denaturing gradient gel electrophoresis analysis of polymerase chain reaction amplified genes coding for 16S rRNA. Appl. Environ. Microbiol. 59, 695-700.

Okabe, S., Satoh, H., Watanabe, Y., 1999. In situ analysis of nitrifying biofilms as determined by in situ hybridization and the use of microelectrodes. Appl. Environ. Microbiol. 65, 3182-3191.

Persson, F., Wik, T., Sorensson, F., Hermansson, M., 2002. Distribution and activity of ammonia oxidizing bacteria in a large full-scale trickling filter. Water Res. 36, 1439-1448.

Possemiers, S., Verthé, K., Uyttendaele, S., Verstraete, W., 2004. PCR-DGGE-based quantification of stability of the microbial community in a simulator of the human intestinal microbial ecosystem. FEMS Microbiol. Ecol. 49, 495-507.

Purkhold, U., Pommerening-Roser, A., Juretschko, S., Schmid, M.C., Koops, H.-P., Wanger, M., 2000. Phylogeny of all recognized species of ammonia oxidizers based on comparative 16S rRNA and amoA sequence analysis: implications for molecular diversity surveys. Appl. Environ. Microbiol. 66, 5368-5382.

Rosenberger, S., Krüger, U., Witzig, R., Manz, W., Szewzyk, U., Kraume, M., 2002. Performance of a bioreactor with submerged membranes for aerobic treatment of municipal waste water. Water Res. 36, 413-420.

Schramm, A., Beer, D., Heuvel, J.C., Ottengraf, S., Amann, R., 1999. Microscale distribution of populations and activities of Nitrosospira and Nitrospira spp. along a macroscale gradient in a nitrifying bioreactor: quantification by in situ hybridization and the use of microelectrode. Appl. Environ. Microbiol. 65, 3690-3696.

Siripong, S., Rittmann, E.B., 2007. Diversity study of nitrifying bacteria in full-scale municipal wastewater treatment plants. Water Res. 41, 1110-1120.

Stamper, D.M., Walch, M., Jacobs, R.N., 2003. Bacterial population changes in a membrane bioreactor for graywater treatment monitored by denaturing gradient gel electrophoretic analysis of 16S rRNA gene fragments. Appl. Environ. Microbiol. 69, 852-860.

Stehr, G., Bottcher, B., Dittberner, P., Rath, G., Koops, H.-P., 1995. The ammonia-oxidizing nitrifying population of the River Elbe estuary. FEMS Microbiol. Ecol. 17, 177-186.

Stephanie, A.E., John, A.B., Thomas, M.S., 2007. Isolation and characterization of soil bacteria that define Terriglobus gen. nov. in the phylum Acidobacteria. Appl. Environ. Microbiol. 73 (8), 2708-2717

Thompson, J.D., Gibson, T.J., Plewniak, F., Jeanmougin, F., Higgins, D.G., 1997. The ClustalX windows interface: flexible strategies for multiple sequence alignment aided by quality analysis tools. Nucleic Acids Res. 25, 4876-4882.

Wittebolle, L., Vervaeren, H., Verstraete, W., Boon, N., 2008. Quantifying community dynamics of nitrifiers in functionally stable reactors. Appl. Environ. Microbiol. 74, 286-293.

Xing, C.H., Tardieu, E., Qian, Y., Wen, X.H., 2000. Ultrafiltration membrane bioreactor for urban wastewater reclamation. J. Memb. Sci. 177, 73-82.

You, S.J., Chen, W.Y., 2008. Ammonia oxidizing bacteria in a nitrite-accumulating membrane bioreactor. Int. Biodeterior. Biodegrad. 62, 244-249. 